\title{
Americans cancel visits in protest over Orlov
}

CONCERn for the fate of Dr Yurii Orlov among his scientific colleagues in the West continues to increase. Already a 20-person delegation from the US National Academy of Science has cancelled its visit to Moscow, in protest against the 12-year sentence imposed on Dr Orlov, and two other American scientists have also cancelled separate missions. In the UK, where the announcement of the verdict came on the eve of the routine biennial London meeting of the British-Soviet Joint Commission for collaboration in science and technology, reactions were equally sensitive. Among other gestures, a letter of protest, signed by some 70 Fellows of the Royal Society has been handed to the delegation.

Responding to foreign concern, the Soviet media have devoted unprecedenied coverage to the Orlov case, both for home and foreign consumption. Not surprisingly, in view of the Soviet desire for continuing scientific contacts with the West, a number of these reports attempt to minimise his role as a scientist.

"Trained as a physicist, Orlov devoted himself exclusively in recent years to compiling tendentious, false information for foreign anti-Soviet publications and radio stations", said Vechernyaya Moskva. "In the past a physicist, Orlov abandoned' his research work in order to engage in fabricating slanderous information... with the aim of undermining the Soviet system", reiterated Moskovskaya Pravda.

However, according to Orlov himself (in a curriculum vitae supplied to Amnesty International) his whole scientific career has been involved with matters of academic and personal freedom. Born shortly after the accession of Stalin, Yurii Orlov grew up an apparently orthodox follower of official doctrine, joining the Party in 1948, while a student at Moscow State University. On graduating in 1953, he began working at the Institute of Theoretical and Experimental Physics. In 1956, his first scientific paper appeared; significantly, this was in Nuovo Cimento. As Orlov himself explains: "This was at the very beginning of freer publication on subjects previously suppressed as 'secret', though they were not in actual fact secret at all". The same year, he represented his country at a conference in Geneva.

However, also in 1956, Orlov delivered a speech at a closed Party meeting in his Institute, calling for increased democratisation. This meeting was called to discuss the documents to be submitted to the 20th Party Con- gress in October of that year. This was the Congress which inaugurated Khrushchev's policy of de-Stalinisation; yet, ironically, Orlov, whose views might well have been cited in defence of such a 'thaw', was dismissed from the Institute, expelled from the Party, and had his name struck out from scientific reports and reviews, since that name, according to officialdom, "brings disgrace to Soviet science". He was forbidden to defend his thesis, and was unable to obtain any scientific or teaching work in Moscow. Finally, he obtained a post in Armenia, working on nonlinear focussing electron accelerator technology.

\section{Making the same point...}

In $\quad$ Sorry, for
Moscow
copyright reasons
$\begin{aligned} & \text { Irina Orlov } \\ & \text { speaking }\end{aligned}$ some images on
outside the
court where page may not
her husband
was on trial

Sorry, for
copyright reasons
some images on In
this page may not
be available online
$\begin{aligned} & \text { John } \\ & \text { Macdonald } \\ & \text { putting the } \\ & \text { case for } \\ & \text { Orlov at } \\ & \text { the mock } \\ & \text { trial }\end{aligned}$
ton

Here, Orlov was able ("with some pressure") to defend his thesis, and later under an amnesty granted by Khrushchev in connection with the celebrations of 40 years of Soviet rule in Armenia, Orlov received back his clearance for 'secret' work. In 1968, he was elected a Corresponding-Member of the Academy of Sciences of the Armenian SSR.

This election, says Orlov, "proved to be a surprise for Moscow", and he became subject to increasing bureaucratic restrictions. In 1973, he returned to Moscow, under conditions which he does not specify, but which suggest a certain pressure. After several months, he found a post at one of the institutes of the Soviet Academy of Sciences, but in 1974 was dismissed after writing a letter defending Academician Sakharov during the 'press campaign' against him.

During his active scientific life, Orlov published at least 25 papers on the theory and technology of synchrotrons and particle physics.

Following his dismissal, when publication through official channels became impossible, he became a regular participant in the 'Sunday Seminars' founded by Aleksandr Voronel for refusnik scientists, one of the very few Gentiles to do so. In 1974, when the seminar group attempted to hold an international symposium (which was frustrated by KGB intervention), Orlov submitted a paper on uncertainty effects, which proposed new variants of the equations of non-local field theory. According to reliable reports, even while in pre-trial custody last year, he completed two papers on symbolic logic and particle theory re\& spectively - these, however, have apparently disappeared into the court files.

Last week John Macdonald, Q.C., who was briefed by Mrs Irina Orlova to defend her husband, on the grounds that no Soviet lawyer could offer an adquate defence, and who was not given a visa to travel to Moscow, presented the 'case for the defence'. With true legal wit, $\mathrm{Mr}$ Macdonald denied that this was a mock trial-on the contrary, he averred, "the mock-trial was in Moscow". The venue for the hearing - the Institute of Physics - was chosen deliberately to stress Orlov's professional affiliation, which the Soviet media seem bent on denying.

Support by scientific colleagues abroad has, on occasion, had considerable success-in 1970, a world-wide outcry from his fellow biologists effected the release of Zhores Medvedev from a Soviet mental hospital. $\mathrm{Mr}$ Macdonald is now preparing an appeal against the Orlov sentence, based on articles 342-343 of the Soviet criminal procedure, which provide for appeal in the case of "onesideness or incompleteness of the enquiry", since witnesses "whose testimony has substantial significance for the case" were not called.

The support already shown, and perhaps to come, to Yurii Orlov by his fellow physicists and by the scientific community at large may well have a significant effect on the outcome of such an appeal.

Vera Rich 